\title{
RESPON TRAUMATIK ANAK-ANAK KORBAN BANJIR BANDANG DI WASIOR PAPUA BARAT
}

\author{
Mulyadi \\ Dosen Penyuluhan dan Komunikasi Pembangunan, \\ Fakultas Peternakan Perikanan dan Ilmu Kelautan (FPPK), \\ Universitas Negeri Papua (UNIPA) \\ Email: mulyadipapua@yahoo.com
}

\begin{abstract}
ABSTRAK. Banjir bandang Wasior Papua Barat meninggalkan duka yang mendalam selain korban jiwa dan harta, yang sulit diprediksi adalah dampak psikologis pascabencana terutama kepada anak-anak. Benseller (2005) menyatakan bahwa anak-anak yang mengalami trauma psikis bila tidak ditangani dengan baik dapat mengalami PTSD (Post Traumatic Stress Disorder) atau gangguan stress yaitu gangguan psikologis yang disebabkan oleh pengalaman ikut menyaksikan atau mengalami langsung peristiwa yang mengerikan. Penelitian studi psikososial ini bertujuan untuk melihat respon traumatik anak-anak korban bencana banjir bandang Wasior pada: 1) respon terhadap pengalaman "rasa takut"; 2) respon terhadap kondisi lingkungan sosial di posko penampungan sementara; 3) respon terhadap proses pembelajaran yang diberikan oleh fasilitator/guru relawan; dan 4) respon terhadap "rasa ingat" sebelum bencana banjir terjadi (kondisi normal). Penelitian menggunakan metode observasi dan wawancara sambil bermain, ketika 15 hari anak-anak korban banjir bandang Wasior dalam pendampingan psikososial oleh Muhammadiyah Disaster Management Center (MDMC). Responden terpilih 20 orang siswa SD kelas 4 sampai dengan 6 . Hasil penelitian menunjukkan bahwa anak-anak korban banjir Wasior mulai berkurang rasa takut (trauma) terhadap peristiwa yang dilihat dan dialaminya. Mereka sudah berani bermain di luar tenda dan bisa tidur nyenyak. Hal ini didukung oleh kondisi lingkungan di posko penampungan, metode belajar yang kreatif dan menyenangkan dari relawan. Maka, kondisi normal tersebut mereka sudah "siap" untuk dikembalikan ke tempat penampungan sementara di Wasior.
\end{abstract}

Kata Kunci: banjir bandang, psikososial, traumatik, rasa takut, rasa ingat

\section{THE TRAUMATIC RESPONSE IN CHILDRENS VICTIMS OF FLASH FLOODS WASIOR WEST PAPUA}

ABSTRACT. Flash floods in Wasior West Papua left a deep sorrow - in addition to loss of life and property, which is difficult to predict the post-disaster psychological impact, especially to children. Benseller (2005) mentions that children who experience 
psychological trauma, if not handled properly will experience PTSD (Post Traumatic Stress Disorder) is a psychological disorder caused by the experience witnessed or experienced directly participate terrible events. The research study aims to look at psychosocial traumatic response in children victims of flash floods Wasior on: 1) a response to the experience of "fear", 2) a response to social environmental conditions in temporary shelters, 3) response to a given learning process by volunteers, and 4) response to the "sense memory" before the flood disasters occur (normal conditions). Research using the method of observation and interview while games, when the 15day flood-affected children in psychosocial assistance by Muhammadiyah Disaster Management Center (MDMC). Selected respondents totaled 20 people from elementary school students grades (class) 4 - 6. Results showed that children of flood victims began to diminish fear (trauma) to the events seen and experienced. They had dared to play outside the tent and can sleep soundly. This is supported by environmental conditions in post camps, creative methods of learning and fun from the volunteers. In normal conditions, then they're "ready" to return to temporary shelters in Wasior.

Keywords: flash floods, psychosocial, trauma, fear, remember

\section{PENDAHULUAN}

Banjir bandang yang datang tiba-tiba pada hari Senin, 4 Oktober 2010 sangat mengagetkan seluruh penduduk kota Wasior Kabupaten Teluk Wandama Provinsi Papua Barat. Saat seluruh warga kota beranjak siap-siap berangkat bekerja dan anakanak ke sekolah pada pagi pukul 07.00 Wit tiba-tiba suara gemuruh air bah disertai benda-benda keras seperti batu, akar-batang pohon bersama lumpur pekat menghantam ke segala penjuru kota Wasior tempat dimana kali Wondiboy bermuara di pantai Wasior. Warga panik menyelamatkan diri menuju daerah yang lebih tinggi sedangkan warga yang tinggal di aliran sungai dan berada di daerah yang rendah banyak menjadi korban. Sekitar 31 rumah penduduk dan fasilitas umum seperti kantor, sekolah, jembatan, pasar, dan rumah ibadah mengalami rusak berat.

Laporan terakhir dari Badan Nasional Penanggulangan Bencana (BNPB) menyebutkan jumlah korban meninggal dunia 144 orang, luka ringan-berat 879 orang, dan dinyatakan hilang 103 orang. Dua hari itu kota Wasior bagai kota mati karena bala bantuan dari luar belum tiba karena terkendala cuaca buruk dan terisolirnya Wasior dari ibu kota provinsi Manokwari dan kota-kota lainnya. Korban bencana yang luka-luka dan anak-anak dibawa menggunakan kapal dan perahu ke RSUD Nabire dan pesawat helikompter ke RSUD Manokwari. Relatif pada hari keenam seluruh korban diungsikan ke posko Manokwari yang berada di dua tempat yaitu lapangan Kodim 1703 dan gedung milik Diklat Kehutanan. 
Data yang dihimpun Lembaga Penanggulangan Bencana (Muhammadiyah Disaster Management Center/MDMC) yang melakukan kegiatan pelayanan kesehatan dan psikososial pada 11 Oktober 2010 menyebutkan jumlah pengungsi 4.475 orang yang tersebar di Manokwari, Nabire dan Wasior. Pengungsi di Manokwari di tempatkan di Posko Lapangan Kodim 1703 dan Diklat Kehutanan. Di antara pengungsi terdapat anak-anak sekitar 560 orang. Presiden Susilo Bambang Yudhoyono dan Ibu Nani Yudhoyono beserta robongan menteri terkait mengunjungi lokasi bencana dan pengungsi di Manokwari.

Sarwono (2001), menyatakan bahwa korban dari kelompok anak-anak merupakan kelompok paling rentan yang menjadi korban dan paling menderita daripada orang dewasa. Mereka belum bisa menyelamatkan dan memulihkan diri dari rasa trauma, sehingga peluang menjadi korban lebih lanjut menjadi besar. Sebagai akibatnya mereka mengalami trauma fisik dan psikis (psikososial) karena kehilangan salah satu orangtua atau keluarganya. Akumulasi trauma psikososial itu bisa berupa reaksi fisik maupun gejala-gejala psikis seperti rasa mual, murung, pendiam, mimpi buruk, kecemasan, merasa terancam, serta hilangnya harapan hidup. Korban bencana alam seperti anak-anak yang mengalami trauma psikis bila tidak ditangani dengan baik dapat mengalami Post Traumatic Stress Disorder (PTSD) atau gangguan stress pascatrauma yaitu gangguan psikologis yang disebabkan oleh pengalaman ikut menyaksikan atau mengalami langsung peristiwa yang yang mengerikan (Benseller, 2005).

Berbagai lembaga lokal dan nasional seperti MDMC bersama Dinas Pendidikan Papua Barat dan Manokwari membuka posko pelayanan psikososial dan kelas-kelas darurat tempat anak-anak kembali belajar seperti sedia kala. Pelayanan psikososial kepada anak-anak seperti bermain, belajar pelajaran sekolah, bernyanyi, mengaji dan berdoa bersama. Sejauh mana tingkat traumatik anak-anak korban bencana banjir bandang Wasior selama dalam pengungsian terungkap dalam hasil penelitian ini.

\section{METODE}

Penelitian ini menggunakan pendekatan psikoanalisis menurut Freud, bahwa sebagian besar perilaku manusia berasal dari proses yang tidak disadari (uncioncious process) yaitu proses pemikiran, rasa takut, keinginan-keinginan yang tidak disadari tetapi berpengaruh terhadap perilaku seseorang. Penelitian ini, dilakukan saat anakanak korban bencana banjir bandang Wasior sedang dalam pendampingan psikososial yang dilakukan oleh Muhammadiyah Disaster Management Center (MDMC) atau sudah 15 hari berada di lokasi penampungan Kodim 1703 dan Diklat Kehutanan Manokwari.

Responden dipilih secara purposif dengan ketentuan anak-anak berumur 9-12 tahun atau siswa SD kelas IV - VI sehingga terpilih 20 orang anak-anak (10 laki-laki dan 10 wanita). Maksud penentuan umur dan tingkat pendidikan responden adalah 
untuk mengurangi bias jawaban responden yakni kemampuan mengabstraksikan pertanyaan-pertanyaan dan wawancara mendalam yang diajukan oleh peneliti.

Pengambilan data dengan metode observasi dan wawancara lewat kegiatan permainan (role games) yakni mengajak anak-anak menjawab pertanyaan sambil bermain. Kepada responden dibagi 3 kartu berwarna hijau yang berarti "sering", kuning berarti "kadang-kadang" dan kartu warna merah yang berarti "tidak pernah". Peneliti membacakan pernyataan sekaligus kalimat pertanyaan yang diulang sebanyak dua kali, setelah itu responden (anak-anak) menjawab dengan mengacungkan tangan sambil memegang kartu warna pilihannya secara bersama-sama.

Sebelum pengambilan data perlu dilakukan latihan permainan beberapa kali hingga responden lancar melakukan permainan tersebut. Setelah permainan selesai dilanjutkan dengan wawancara mendalam tentang apa yang dialami dan dirasakan ketika bencana terjadi dan saat berada di tempat penampungan, yaitu melengkapi data kuantitatif pada variabel: 1) rasa takut, 2) lingkungan fisik dan sosial, 3) kegiatan belajar, dan 4) ingatan masa lalu.

Data kuantitatif diperoleh dari kategori sebagai berikut: 1) Skor item pernyataan: $1-6=$ rendah, $7-12=$ sedang, dan $13-20=$ tinggi; dan 2) skor respon traumatik: 1 $-53=$ kurang, $54-107=$ sedang, $108-160=$ tinggi .

\section{HASIL DAN PEMBAHASAN}

Hasil pengamatan terhadap rasa takut anak-anak korban pascabanjir bandang Wasior seperti terlihat pada Tabel 1 (Responden $=20$ ). Dari Tabel 1 dapat dijelaskan bahwa selama 15 hari di penampungan pengungsi anak-anak sudah mulai kurang rasa takut tentang peristiwa yang mereka alami yaitu skor 55 . Hal ini ditunjukkan oleh respon mereka ketika menonton berita di televisi yang sering menyiarkan informasi tentang bencana banjir ikut mengurangi rasa takut (skor 8). Demikian juga suara hujan dan angin di luar tenda tidak mempengaruhi rasa takut (skor 11), dan malam hari mereka sudah mulai nyenyak tidur (skor 8). Kendatipun ketika peristiwa banjir terjadi di Wasior didahului oleh suara hujan, angin dan dilanjutkan dengan gemuruh air yang mengalir deras dari atas gunung.

Rasa takut pada anak-anak menurut Vernberg dalam Amriel (2008) tidak bisa lenyap begitu saja atau bersifat sementara selama proses pengalihan kondisi dan perhatian berlangsung. Karena proses lupa berjalan secara samar-samar hingga akhirnya melupakan peristiwa aslinya. Korban hanya mengingat peristiwa yang menonjol dari peristiwa yang pernah dialaminya.

Dengan kondisi yang berangsur normal, anak-anak sudah berani bermain-main di luar tenda (skor 12) bahkan pada malam hari sudah bisa tidur nyenyak (skor 8). Hanya saja mereka masih merasa sangat takut ketika mendengar cerita dari orangorang yang berkerumun menceritakan tentang kronologis peristiwa banjir tersebut 
terjadi (skor 10), sehingga kalau ingin bermain-main di luar tenda masih harus ramairamai atau berombongan bersama teman-teman yang satu tenda (skor 11).

Oleh sebab itu pengalihan kondisi anak-anak selama di penampungan sangat perlu dilakukan dengan cara menyiapkan fasilitas bermain sambil belajar di dalam maupun di luar ruangan, dijauhkan dari kerumunan orang-orang dewasa dan menonton televisi yang menayangkan berita tentang bencana tersebut.

Tabel 1. Nilai Skor Respon terhadap Rasa Takut Anak-anak Korban Banjir Bandang Wasior

\begin{tabular}{llccc}
\hline No. & \multicolumn{1}{c}{ Indikator } & Sering & $\begin{array}{c}\text { Kadang- } \\
\text { kadang }\end{array}$ & $\begin{array}{c}\text { Tidak } \\
\text { Pernah }\end{array}$ \\
\hline 1. & $\begin{array}{l}\text { Masih rasa takut mendengar cerita tentang } \\
\text { banjir di Wasior }\end{array}$ & $\mathbf{1 0}$ & 4 & 6 \\
\hline 2. & $\begin{array}{l}\text { Masih rasa takut menonton televisi yang } \\
\text { memberitakan banjir Wasior }\end{array}$ & 7 & $\mathbf{8}$ & 5 \\
\hline 3. & $\begin{array}{l}\text { Masih rasa takut tinggalkan ruangan/tenda } \\
\text { penampungan untuk bermain diluar }\end{array}$ & 3 & 5 & $\mathbf{1 2}$ \\
\hline 4. & $\begin{array}{l}\text { Bermain diluar ruangan/tenda harus ramai- } \\
\text { ramai dengan teman }\end{array}$ & $\mathbf{1 1}$ & 5 & 4 \\
\hline 5. & $\begin{array}{l}\text { Masih rasa takut kalau ada hujan deras dan } \\
\text { bunyi angin di luar ruangan/tenda }\end{array}$ & 3 & $\mathbf{1 1}$ & 6 \\
\hline 6. & $\begin{array}{l}\text { Masih tidur bersama orang tua kalau tidur } \\
\text { pada malam hari }\end{array}$ & 7 & 7 & 6 \\
\hline 7. & Masih sulit tidur pada malam hari & 5 & 7 & $\mathbf{8}$ \\
\hline 8. & Masih terbangun pada tengah malam & 5 & $\mathbf{8}$ & 7 \\
\hline & $\quad$ Total & 51 & $\mathbf{5 5}$ & 54 \\
\hline
\end{tabular}

Peristiwa yang sangat melekat pada pikiran anak-anak dalam peristiwa banjir tersebut adalah dahsatnya banjir menerjang rumah mereka dengan suara gemuruh datang dari arah gunung. Seketika itu juga sekeluarga menyelamatkan diri ke daerah yang lebih tinggi namun ada yang tidak bisa menyelamatkan diri hanyut terbawa oleh banjir. Ketika banjir sudah surut anak-anak melihat mayat-mayat tertimbun lumpur, terjepit diantara puing-puing batang pohon dan benda-benda keras lainnya. Sangat terasa bagi anak-anak yang orang tua atau saudara-saudaranya tewas atau hilang disapuh banjir bandang. "Saya melihat sendiri ibu saya mengambil barangnya tertinggal di dalam rumah, sampai ibu saya hilang," ungkap responden yang kehilangan salah satu orang tuanya itu.

Menurut Amriel (2008), ketakutan pada anak-anak merupakan suatu keadaan alamiah dan sebatas pada hal-hal yang spesifik dalam rangka membantu individu 
melindungi dirinya dari suatu bahaya sekaligus memberi pengalaman baru. Bentuk ekspresi ketakutan lewat tangisan, jeritan, bersembunyi atau tak mau lepas dari orang tuanya. Oleh sebab itu bagi anak-anak korban bencana alam selama di penampungan diperlukan perlakuan khusus berbeda dengan orang dewasa.

Menurut Benseller (2005), gangguan stress pascatrauma nampak setelah sebulan atau setahun setelah bencana dengan memperlihatkan ciri selalu diburu oleh ketakutan yang berhubungan dengan bencana yang dialaminya seperti ketakutan akan berpisah dari orangtua untuk selama-lamanya dan sering mengalami gangguan dalam tidur dengan mimpi-mimpi buruk, menjerit, dan mengompol di tempat tidur.

\section{Respon terhadap Lingkungan Sosial di Penampungan}

Hasil pengamatan respon terhadap lingkungan fisik dan sosial di penampungan ditunjukkan seperti Tabel 2 (Responden $=20$ ). Kondisi tempat penampungan sementara di lapangan Kodim 1703 dan Diklat Kehutanan mempengaruhi pemulihan psikologis anak-anak korban banjir terlihat dari skor 66 bahwa rasa tarauma sudah mulai hilang. Hal ini terlihat dari skor indikator pengamatan pada hubungan orang tua dengan anak-anak mereka jarang emosional lagi atau marah-marah (skor 12), demikian juga sesama teman (peer group) jarang terjadi perkelahian (skor 10). Di penampungan anak-anak kadang-kadang menerima uang jajan dari orang tua mereka (skor 10) yang diterima dari bantuan pemerintah, lembaga donor, dan perseorangan kepada para pengungsi.

Menurut Fahrudin (2008), peran orang tua, keluarga dan lingkungan dianggap sangat penting karena mereka adalah orang-orang secara kontak langsung dekat dengan anak-anak. Karena pada masa-masa pemulihan banyak faktor lingkungan seperti rasa aman, terlindungi, perhatian, kegembiraan, dan kebersamaan diperlukan untuk mengobati rasa pascabencana. Oleh sebab itu keadaan lingkungan di tempat penampungan harus dikondisikan sesuai dengan dunia anak-anak yang memiliki sifat sangat unik dan masa dimana anak-anak mengenal lingkungan sekitar sambil bermain seperti di sekolah.

Keluhan para anak-anak adalah ketika masuk waktu jadwal makan sering mengalami keterlambatan. "Kita makan sering terlambat karena di dapur makanan juga terlambat," kata salah satu responden mewakili teman-temannya. Hasil pengamatan peneliti diketahui bahwa posko telah mendirikan dapur umum, diberikan bantuan alat-alat masak dan makan kepada setiap keluarga untuk memasak sendiri di dapur. Keterlambatan tersebut diduga karena terbatasnya tungku masak yang disediakan oleh posko sehingga harus bergiliran. Anak-anak bisa terobati rasa lapar dengan membeli makanan ringan di kios terdekat atau makanan siap saji seperti mie instan pemberian posko bantuan. 
Tabel 2. Nilai Skor Respons terhadap Lingkungan Fisik dan Sosial Anak-anak Korban Banjir Bandang Wasior

\begin{tabular}{llccc}
\hline No. & \multicolumn{1}{c}{ Indikator } & Sering & $\begin{array}{c}\text { Kadang- } \\
\text { kadang }\end{array}$ & $\begin{array}{c}\text { Tidak } \\
\text { Pernah }\end{array}$ \\
\hline 1. & $\begin{array}{l}\text { Di penampungan bermain dengan teman- } \\
\text { teman }\end{array}$ & $\mathbf{8}$ & $\mathbf{8}$ & 4 \\
\hline 2. & $\begin{array}{l}\text { Di penampungan anak-anak disediakan } \\
\text { makan dan minum }\end{array}$ & $\mathbf{9}$ & 6 & 5 \\
\hline 3. & $\begin{array}{l}\text { Di penampungan anak-anak mendapat } \\
\text { uang jajan }\end{array}$ & 4 & $\mathbf{1 0}$ & 6 \\
\hline 4. & $\begin{array}{l}\text { Di penampungan anak-anak berkelahi dan } \\
\text { saling marah }\end{array}$ & 4 & $\mathbf{1 0}$ & 6 \\
\hline 5. & $\begin{array}{l}\text { Di penampungan bapak dan mama marah- } \\
\text { marah kepada anak-anak }\end{array}$ & 3 & $\mathbf{1 2}$ & 5 \\
\hline 6. & $\begin{array}{l}\text { Di penampungan kakak petugas jaga } \\
\text { marah-marah kepada anak-anak }\end{array}$ & 4 & $\mathbf{8}$ & $\mathbf{8}$ \\
\hline 7. & Di penampungan bisa mandi setiap hari & $\mathbf{1 1}$ & 5 & 4 \\
\hline 8. & Di penampungan malam hari terasa dingin & 2 & 7 & $\mathbf{1 1}$ \\
\hline & $\quad$ Total & 45 & $\mathbf{6 6}$ & 49 \\
\hline
\end{tabular}

\section{Respon terhadap Proses Pembelajaran}

Respons anak-anak terhadap kegiatan belajar yang diselenggarakan di lokasi penampungan terlihat pada Tabel 3 (Responden $=20$ ). Kegiatan pembelajaran (belajar dan mengajar) yang dilakukan oleh tenaga-tenaga relawan kepada anak-anak korban banjir di lokasi penampungan sementara sudah berlangsung dengan baik dengan skor 74, dalam rangka mengembalikan rasa trauma akan musibah yang mereka alami ketika berada di Wasior dahulu. Relawan yang sering disebut "Ibu Guru" kepada pengajar wanita dan "Bapak Guru" kepada pengajar pria telah membuat suasana pembelajaran yang menyenangkan dan penuh keakraban. Ditunjukkan dengan kegembiraan ketika belajar berkelompok (skor 10), pengajar dengan senyum dan ramah (skor 13) menyapa setiap anak dengan cara menyebutkan nama-nama mereka satu per satu (skor 13). Relawan dalam mengajar telah menggunakan alat bantu seperti gambar sambil bercerita atau mendongeng, serta bernyanyi (skor 15). Untuk menarik perhatian siswa mau belajar relawan menggunakan pendekatan Paikem yaitu pembelajaran aktif, inovatif, kreatif dan menyenangkan yang selama ini belum mereka jumpai di sekolah sebelumnya di Wasior. 
Tabel 3. Nilai Skor Respon terhadap Kegiatan Belajar Anak-anak Korban Banjir Bandang Wasior

\begin{tabular}{|c|c|c|c|c|}
\hline No. & Indikator & Sering & $\begin{array}{l}\text { Kadang- } \\
\text { kadang }\end{array}$ & $\begin{array}{c}\text { Tidak } \\
\text { Pernah }\end{array}$ \\
\hline 1. & $\begin{array}{l}\text { Di penampungan setiap hari anak-anak } \\
\text { bersama ibu/bapak guru belajar seperti di } \\
\text { sekolah dulu }\end{array}$ & 7 & 8 & 5 \\
\hline 2. & Guru membuat anak-anak merasa takut & 5 & 3 & 12 \\
\hline 3. & $\begin{array}{l}\text { Guru menggunakan alat bantu (gambar, } \\
\text { menyanyi, dan bercerita) dalam mengajar }\end{array}$ & 15 & 3 & 2 \\
\hline 4. & $\begin{array}{l}\text { Guru tersenyum dan berbicara dengan } \\
\text { nada ramah kepada anak-anak }\end{array}$ & 13 & 5 & 2 \\
\hline 5. & $\begin{array}{l}\text { Di penampungan disediakan alat-alat } \\
\text { belajar seperti buku tulis, pensil, dan buku } \\
\text { bacaan }\end{array}$ & 3 & 6 & 11 \\
\hline 6. & $\begin{array}{l}\text { Di penampungan diajarkan untuk bersabar, } \\
\text { berdoa, sembahyang atau mengaji oleh } \\
\text { ibu/bapak guru }\end{array}$ & 8 & 9 & 3 \\
\hline 7. & $\begin{array}{l}\text { Anak-anak mengerjakan tugas bersama } \\
\text { atau berkelompok }\end{array}$ & 10 & 8 & 2 \\
\hline \multirow[t]{2}{*}{8.} & $\begin{array}{l}\text { Guru memanggil anak-anak dengan } \\
\text { menyebut nama }\end{array}$ & 13 & 5 & 2 \\
\hline & Total & 74 & 47 & 39 \\
\hline
\end{tabular}

Asmani (2011) menyatakan bahwa dalam pembelajaran metode PAIKEM (Pembelajaran Aktif Inovatif Kreatif Efektif dan Menyenangkan) selain melatih sabar, tekun, ulet dan meningkatkan daya ingat anak-anak, juga harus dapat SSN (senyum, santai, dan nikmat). Artinya siswa harus selalu tersenyum (dalam hati) saat melakukan semua proses kegiatan pembelajaran, sehingga lama kelamaan akan melupakan kesan-kesan yang melukai anak-anak tersebut. Dikatakan oleh Benseller (2005) anakanak korban bencana memperlihatkan sifat suka menyendiri, tidak peduli diri, kurang melakukan aktivitas, dan selalu berpikir pada bencana yang terjadi.

Walaupun mereka belajar di bawah tenda dengan peralatan belajar (buku tulis, buku bacaan, dan pensil) yang kurang -- tidak seperti di kelas yang normal, maka melalui metode mengajar yang aktif, kreatif, dan menyenangkan mengajak anak-anak bergembira dan sudah mulai banyak tersenyum melupakan trauma yang mereka alami. Rata-rata mereka menyatakan Ibu dan Bapak Guru tidak pernah menampakkan kemarahan kepada mereka (skor 12), di samping kadang-kadang (skor 9) diajak untuk 
menanamkan rasa sabar dengan selalu mengingat kepada Tuhan yang Maha Kuasa melalui kegiatan mengaji, sembahyang dan berdoa selama di penampungan. Anakanak senang karena kegiatan yang dilakukan relawan sangat menarik, menantang, dan meningkatkan motivasi serta membuat anak-anak tidak merasa takut.

Menyenangkan adalah suasana belajar mengajar yang nyaman, sehingga siswa dapat memusatkan perhatiannya secara penuh pada belajar dan waktu curah perhatiannya menjadi tinggi. Menabur kegembiraan dan keceriaan pada anak, akan membuatnya mampu mengaaktualisasikan kemampuan dalam bentuk yang sempurna (Asmani, 2011).

\section{Respon terhadap Rasa Ingat Masa Normal}

Hasil respon anak-anak pengungsi terhadap ingatan masa normal atau sebelum terjadi bencana diperlihatkan dalam Tabel 4 (Responden $=20$ ). Pada Tabel 4 secara umum menunjukkan bahwa daya ingat (recall) anak-anak korban bencana banjir Wasior terhadap kejadian sebelum peristiwa banjir dan ketika banjir terjadi (skor 138) sangat tinggi, yaitu tentang rumah tempat tinggal, sekolah, guru, teman sepermainan, orang tua, dan bagaimana kronologis peristiwa tersebut telah menimpa mereka (skor 14-20). Terutama yang masih terngiang dalam ingatan anak-anak korban tersebut adalah bermain di kali dan laut bersama teman-teman dan orang tua telah membantu menyelamatkan mereka dari terjangan banjir setinggi tiga meter dengan cara melarikan diri ke daerah yang dirasakan aman.

Hal ini pengaruh faktor personal dalam memori. Pemulihan melalui pendampingan psikososial telah memulihkan memori atau ingatan trauma menjadi jiwa yang stabil seperti sebelum peristiwa banjir bandang terjadi. Rahmat (1998) menyatakan bahwa daya ingat adalah proses ketiga setelah perekaman dan penyimpanan informasi dalam memori yang sanggup merekam fakta suatu peristiwa dalam otak, apalagi peristiwa yang sangat terkesan seperti terjadi bencana. Memori pada anak-anak sangat cepat menerima respons dan cepat juga informasi tersebut menghilang asalkan dilakukan proses belajar untuk mengalihkan perhatian kepada hal-hal yang membuat anak-anak trauma (Hunt, 1982).

Tingginya daya ingat anak-anak tersebut menunjukkan bahwa anak-anak memiliki ikatan psikologis dengan daerah asal mereka, peristiwa traumatik, dan keseharian mereka yaitu dunia bermain. Hal ini menjelaskan kepada kita bahwa korban bencana bisa dikembalikan ke daerah asal di Wasior, apabila kondisi selama di penampungan sudah pulih seperti semula. Pemulihan dilakukan dengan kegiatan-kegiatan belajar sambil bermain yang dilakukan oleh relawan selama mereka berada di penampungan. Harapannya ketika seluruh pengungsi dikembalikan ke pemukiman baru di Wasior sudah berdiri dan tersedia fasilitas seperti sebelum terjadi bencana. 
Tabel 4. Nilai Skor Respon terhadap Ingatan Masa Normal Anak-anak Korban Banjir Bandang Wasior

\begin{tabular}{llccc}
\hline No. & \multicolumn{1}{c}{ Indikator } & Sering & $\begin{array}{c}\text { Kadang- } \\
\text { kadang }\end{array}$ & $\begin{array}{c}\text { Tidak } \\
\text { Pernah }\end{array}$ \\
\hline 1. & $\begin{array}{l}\text { Masih ingat tentang rumah adik-adik di } \\
\text { Wasior }\end{array}$ & $\mathbf{1 4}$ & 6 & 0 \\
\hline 2. & $\begin{array}{l}\text { Masih ingat tentang sekolah adik di Wasior } \\
\text { 3. }\end{array}$ & $\mathbf{1 4}$ & 4 & 2 \\
\hline $\begin{array}{l}\text { Masih ingat tentang Ibu dan Bapak Guru di } \\
\text { Wasior }\end{array}$ & $\mathbf{1 5}$ & 0 & 5 \\
\hline 4. & $\begin{array}{l}\text { Masih ingat teman-teman bermain di } \\
\text { Wasior }\end{array}$ & $\mathbf{1 5}$ & 0 & 5 \\
\hline 5. & $\begin{array}{l}\text { Masih ingat tentang mandi di kali atau di } \\
\text { laut di Wasior }\end{array}$ & $\mathbf{2 0}$ & 0 & 0 \\
\hline 6. & $\begin{array}{l}\text { Masih ingat ibu dan bapak memberi uang } \\
\text { belanja/jajan sekolah di Wasior }\end{array}$ & $\mathbf{2 0}$ & 0 & 0 \\
\hline 7. & $\begin{array}{l}\text { Masih ingat tentang bapak dan ibu } \\
\text { menolong adik waktu banjir }\end{array}$ & $\mathbf{2 0}$ & 0 & 0 \\
\hline 8. & $\begin{array}{l}\text { Masih ingat tentang bagaimana kejadian } \\
\text { banjir di Wasior }\end{array}$ & $\mathbf{2 0}$ & 0 & 0 \\
\hline
\end{tabular}

Wiryasaputra (2008), menyatakan setelah melakukan proses normalisasi atau penyembuhan pada korban bencana; maka akhirnya individu, keluarga atau komunitas tertentu dapat menerima kenyataan tentang bencana yang dialaminya. Menyerah dalam arti yang positif (tawakal), bukan putus asa merupakan titik tolak pertumbuhan baru. Dalam tahap tertentu mereka sudah siap membangun kembali lingkungannya. Pikiran mereka sudah jernih. Tenaga batin sosial, fisik dan spiritual, daya juang mereka sudah pulih.

Masa kanak-kanak penting diperhatikan karena masa ini masa-masa emas menumbuhkembangkan baik dari segi fisik, kognitif, emosi, sosial, moral, dan sebagainya. Bila masa-masa penampungan tidak diperhatikan maka cenderung menghambat proses pemulihan dari traumatik dan perkembangannya bahkan bisa terjadi cacat secara mental. Peran lembaga perbantuan dan lingkungan dianggap sangat penting karena mereka adalah orang-orang secara kontak langsung dekat dengan anak-anak korban. 


\section{SIMPULAN}

Secara perlahan selama 15 hari diberikan pelayanan psikososial bagi anak-anak korban bencana banjir bandang Wasior mulai berkurang rasa takut (trauma) terhadap peristiwa yang dilihat dan alaminya. Mereka sudah merasa aman bermain di luar tenda dan pada malam hari sudah bisa tidur nyenyak;

Kondisi lingkungan sosial di posko penampungan sementara sangat mempengaruhi mempercepat pemulihan kondisi anak-anak korban pascabencana seperti bermain bersama teman-teman, kasih sayang orang tua, keakraban petugas posko dan guru pendamping selama belajar;

Melalui metode belajar yang aktif, inovatif, kreatif, dan menyenangkan oleh relawan yang menjadi guru pendamping berhasil mengalihkan trauma anak-anak pascabencana dengan memperlihatkan sikap dan perilaku yang aktif, gembira, tolong menolong, optimis, dan sabar menghadapi cobaan yang mereka alami;

Selama proses pendampingan psikososial kepada anak-anak korban banjir bandang Wasior dilakukan telah memulihkan kembali ingatan (recall) terhadap suasana kondisi sebelum terjadi bencana dalam rangka membangkitkan rasa optimisme untuk kembali ke Wasior seperti sedia kala.

Penelitian traumatik pada anak-anak korban pascabencana banjir bandang Wasior dapat dilanjutkan ketika mereka berada di pemukiman sementara di Wasior untuk melihat sejauhmana pengaruh lingkungan baru dan perubahan psikososial pada pemulihan terakhir;

Pemulihan traumatik bagi anak-anak korban pascabencana tidak hanya dilakukan selama di penampungan sementara, tetapi terus dilanjutkan pendampingan oleh petugas Pemda di Wasior hingga keluarga mereka sudah memiliki tempat pemukiman atau rumah yang tetap.

\section{DAFTAR PUSTAKA}

Amriel, Reza, I. 2008. Memberdayakan Korban Bencana, Psikologi Disaster. http//kangkangari.wordpress.com

Asmani, J. M. 2011. 7 Tips Aplikasi Pakem (Pembelajaran Aktif, Kreatif, Efektif, dan Menyenangkan), Menciptakan Metode Pembelajaran yang Efektif dan Berkualitas. Yogyakarta: Diva Press.

Benseller, Alan. 2005. Anak-anak Situ Gintung, Bagaimana Kabarmu? E-Newsletter Edisi 07 Juli 2009. Yogyakarta: LP3Y, Lembaga Penelitian Pendidikan dan Penerbitan Yogya

Hunt, M. 1982. The Universe Within, A New Science Explores The Human Mind. New York: Simon \& Schuster. 
Respon Traumatik Anak-Anak Korban Banjir Bandang di Wasior Papua Barat (Mulyadi)

Fahrudin, Adi. 2008. Karakter Psikososial Korban Bencana. http://altanwir. wordpress.com /2008 /02/ 14/

Sarwono, Sarlito, W. 2001. Psikologi Sosial, Psikologi Kelompok dan Psikologi Terapan. Jakarta: Balai Pustaka.

Wiryasaputra, S.Totok. 2008. Pelayanan Psikologis Paska Bencana Traumatik (PPPBT), Post-traumatic Disaster Psychological Services. Psikologi Disaster. http//kangkangari. wordpress.com 